DOI: $\underline{10.20472 / E S .2016 .5 .1 .005 ~}$

\title{
EFFECTS OF MACROECONOMIC POLICY SHOCK ON THE LABOUR MARKET DYNAMICS IN AUSTRALIA
}

\section{MUKTI NATH SUBEDI}

\begin{abstract}
:
Inspired by fiscal and monetary policy performance during global financial crisis (GFC) of 2007-08, this study investigates the effects of macroeconomic policy shocks on the labour market dynamics in Australia using a vector auto-regression (VAR) method. This study examines the dynamic response of output, unit labour cost, total hours worked and employment to changes in government spending and cash rate for 1985:3-2015:1. The results suggest that in response to positive cash rate shock total hours worked and employment react negatively, whereas unit labour cost reacts positively. On the other hand, in response to positive government spending shock, total hours worked and employment response positively, whereas, unit labour cost responds negatively.
\end{abstract}

\section{Keywords:}

Labour market, Vector Autoregression, Macroeconomic policy

JEL Classification: C32, E24, E69

\section{Authors:}

MUKTI NATH SUBEDI, Australian National University, Australia, Email:

\section{Citation:}

MUKTI NATH SUBEDI (2016). Effects of macroeconomic policy shock on the labour market dynamics in Australia. International Journal of Economic Sciences, Vol. V(1), pp. 71-85.,

10.20472/ES.2016.5.1.005 


\section{Introduction}

Fiscal and monetary policy have played an important role dealing with the unfavorable economic conditions during the global financial crisis (GFC) of 2007. More importantly, fiscal policy showed its importance in stabilizing the economy during the recession. Many advanced economies, including Australia, announced the significant amount of fiscal stimulus packages to protect the economy from the potential risk of GFC (IMF 2009). On the other hand, monetary policy is considered as the best tool to stabilize the economy in the short run compared to fiscal policy because approval of fiscal policy needs to pass through several channels and political barrier (Romer 2012). However, during the economic downturn, in many advanced economies, the monetary policy was ineffective, as real interest rate was substantially low or negative. However, Australia was an exception as the interest rate at that time did not fall below the nominal $3 \%$ level. Inspired by the performance of Australia's fiscal and monetary policy during GFC, this study analyzes the impacts of macroeconomic policy shocks on the Australian labour market using a vector auto-regression (VAR) method. To be specific, it analyzes the dynamic response of output, real unit labour cost, total hours worked and employment to the government spending shock and cash rate shock.

Labour market responded differently in different regions during the GFC. For instance, in the United States, the highest unemployment rate during GFC was five percentage points higher than the pre-recession rate (Daly et al. 2014). In Australia, the unemployment rate rose to $5.8 \%$ from $4.1 \%$ and the number of employed people decreased by 200,000 during the period of GFC (ABS 2010). As mentioned in ABS (2010), the impact of the economic downturn is not limited on decreasing employment, it affects labour force participation rate and share of full-time and part-time work. So, it is important to understand the effects of fiscal and monetary policy on different labour market variables.

The vector auto regression (VAR) model has been widely used to analyze the transmission mechanism of macroeconomic policies after Sims (1980). So far, several studies (such as Dungey \& Pagan 2000, 2009; Dungey and Fry 2010) have used VAR approach in analyzing the effects of macroeconomic shocks on the Australian economy. However, no attention was given in analyzing the effects on the labour market in their studies. 
Outside Australia, many studies have analyzed the effects of macroeconomic policy shocks on the labour market. Majority of the studies focus on the US. For instance, Yuan \& Li (2000), Monacelli et al. (2010) and Bruckner \& Pappa (2012) investigate the effects of fiscal policy shock on labour market of US. Among them, Bruckner \& Pappa (2012) studied the impact of government spending shock on the labour market, particularly on unemployment and labour force participation for OECD countries including Australia. The result suggests that following the positive government spending shock unemployment, participation rate and employment rate rise for most OECD countries including Australia. Tagkalakis (2006) investigates the impact of a government spending shock in the UK labour market. The study found that positive government spending shock leads to a negative response of employment, hours and output. However, it leads to a positive response of real wages. Similarly, Kato and Miyamato (2013) investigate the impact of fiscal policy shock on the Japanese labour market including both employment and unemployment in their VAR model. Their study found that following positive government spending shock, employment and wages rise however unemployment falls.

Christiano et al. (1999) study the impacts of monetary policy on the US. Their major findings regarding the labour market variables are; following the contractionary monetary policy shock employment and wage rate response negatively. Peersman \& Smets (2001) investigates the impact of contractionary monetary policy shock on the economy of Euro area. Their findings are in line with Christiano et al. (1999) for employment. However, unit labour cost and nominal wage responds positively (Peersman \& Smets 2001). Tagkalakis (2006) analyzes the impact of monetary policy shock on the UK labour market following the identification approach of Chiristiano et al. (1999). The study shows that following the contractionary monetary policy employment, hours and wage responds negatively.

The results from this study suggest that following a contractionary monetary policy shock output, employment and total hours worked responds negatively and follow the hump-shaped pattern. However, unit labour cost responds positively. In response to positive government spending shock output, employment and total hours worked 
responses positively but unit labour cost shows positive response within first three quarters than it shows negative response.

The rest of the paper is organized as follows: Section (2) discuss the empirical model with identification strategies for monetary policy and fiscal policy shocks, section (3) discusses the data including lag length criteria and VAR stability test, section (4) discusses the results and section (5) concludes.

\section{Empirical Model}

The vector autoregression (VAR) model is used to analyze the effects of fiscal policy and monetary policy shocks in the labour market of Australia.

The reduced VAR model takes the following form:

$$
Y_{t}=\sum_{i=1}^{n} K_{i} Y_{t-i}+D J_{t}+e_{t}
$$

Where the $n$-dimensional vector $Y$ includes set of nine endogenous variable of interest; government spending $\left(g_{t}\right)$, net tax $\left(t_{t}\right)$, real gross domestic product $\left(y_{t}\right)$, households consumption expenditure $\left(c_{t}\right)$, private investment $\left(i n v_{t}\right)$, unit labor cost $\left(w_{t}\right)$, total hours worked $\left(h_{t}\right)$, employment $\left(l_{t}\right)$ and cash rate $\left(i_{t}\right)$. $K_{i}$ Is the $n \times n$ matrix of coefficients, $n$ is the optimal number of included lags which is determined based on information criteria, AIC. The vector of reduced form residuals $e_{t}$ is $n$-dimensional with the variancecovariance matrix $\sum_{e}$, where $E\left(e_{t} e_{t}^{\prime}\right)=0$.

$J_{t}$ contains the exogenous variables; real GDP of United States and dummy for global financial crisis (GFC) of 2007-08, included in the model. These exogenous variables capture the shocks originated outside Australia because small open economy is more likely to be affected by the shocks which are originated outside the domestic economy.

The structural VAR model takes the following form:

$$
A_{0} Y_{t}=\sum_{i=1}^{n} A_{i} Y_{t-i}+B v_{t}
$$

The matrix $A_{0}$ describes the contemporaneous relationship among the variables. The matrix $B$ describes the relation between the reduced form residual $e_{t}$ and the structural form residuals $v_{t}$ such that

$$
A_{0} e_{t}=B v_{t}
$$


The analysis is done in e-views programming with the form $A e=B v$ known as AB SVAR.

\subsection{Identification of fiscal policy shocks}

This study follows the assumption of Blanchard and Perotti (2002) and identifies the effects of fiscal policy shock based on the institutional information. In this spirit fiscal variables (government spending) is predetermined comparing to other endogenous variables included in the vector autoregressive model and it does not react contemporaneously with output and other variables within same quarter. This assumption is utilized here by ordering government spending first in the model and using Choleski decomposition (recursive ordering).

Imposing recursive ordering in the VAR model the contemporaneous impact matrix $A_{0}$ will take the lower triangular matrix form and $B$ will be the identity matrix of $9 \times 9$ order.

$$
A_{0}=\left[\begin{array}{ccccccccc}
1 & 0 & 0 & 0 & 0 & 0 & 0 & 0 & 0 \\
t_{21} & 1 & 0 & 0 & 0 & 0 & 0 & 0 & 0 \\
t_{31} & t_{32} & 1 & 0 & 0 & 0 & 0 & 0 & 0 \\
t_{41} & t_{42} & t_{43} & 1 & 0 & 0 & 0 & 0 & 0 \\
t_{51} & t_{52} & t_{53} & t_{54} & 1 & 0 & 0 & 0 & 0 \\
t_{61} & t_{62} & t_{63} & t_{64} & t_{65} & 1 & 0 & 0 & 0 \\
t_{71} & t_{72} & t_{73} & t_{74} & t_{75} & t_{76} & 1 & 0 & 0 \\
t_{t_{1}} & t_{82} & t_{83} & t_{84} & t_{85} & t_{86} & t_{87} & 1 & 0 \\
t_{91} & t_{92} & t_{93} & t_{94} & t_{95} & t_{96} & t_{97} & t_{98} & 1
\end{array}\right], e_{t}=\left[\begin{array}{c}
e_{g} \\
e_{t} \\
e_{y} \\
e_{c} \\
e_{i n v} \\
e_{w} \\
e_{h} \\
e_{l} \\
e_{i}
\end{array}\right] \quad \text { and } v_{t}=\left[\begin{array}{c}
v_{g} \\
v_{t} \\
v_{y} \\
v_{c} \\
v_{i n v} \\
v_{w} \\
v_{h} \\
v_{l} \\
v_{i}
\end{array}\right]
$$

Being consistent with major VAR specification (such as Blanchard \& Perotti 2000; Perotti 2005; Bilbiie et al. 2008) effects of fiscal policy shock are analyzed by assuming government spending is not affected contemporaneously by other variables included in the model. So, government spending, real output, household consumption expenditure, private investment, real unit labour cost, total hours worked, employment and interest rate are ordered from first to last.

This recursive ordering has following implications: 1) government spending does not react contemporaneously to the shocks of other variables, 2) tax does not react contemporaneously to other variables except government spending 3) output does not react contemporaneously to other variables but is affected by government spending and tax shock 4) private consumption is affected by government spending, tax and output 
shock but does not react contemporaneously to other variables 5) private investment is affected by spending, tax, output and consumption shocks however does not reacts with other shock contemporaneously 6) unit labour cost affected by other variables except hours worked, employment and interest rate shocks 7) hours worked is affected by variables except employment and interest rate shocks 8) employment is affected by all variables however does not reacts contemporaneously to interest rate shock and 9) interest rate is contemporaneously affected by all variables included in the system. This identification strategy and choice of variables are made based on Monacelli et al. (2010), Kato and Miyamato (2013) and Tagkalakis (2006).

\subsection{Identification of monetary policy shock}

Following Christiano et al. (1999), it is assumed that monetary authority responds in a systematic way to 'variation in the state of the economy' and set the nominal interest rate based on the set of information according to the following equation:

$$
i_{t}=f\left(K_{t}\right)+\sigma_{s} \varepsilon_{t}^{i}
$$

Where $i_{t}$ is the monetary authority instrument; in our case overnight cash rate, $K_{t}$ is the set of information, $f$ denotes the functional relationship to the information set, $\sigma_{s} \varepsilon_{t}^{i}$ is the monetary policy shock. The recursive approach is adopting in this paper, so fiscal decision are taken prior to the monetary decision and there are no contemporaneous response of variables in information set to the overnight cash rate. In VAR model this relationship is incorporated by ordering fiscal and labour market variables before monetary policy variable similar to the matrix $A_{0}$ in previous sub-section.

\section{Data}

The real gross domestic product, real government spending, net taxes (taxes net transfer), employment rate, household consumption, private investment and quarterly hours worked in all jobs data are taken from Australian Bureau of Statistics (ABS). All of these series are seasonally adjusted. Government spending is calculated as the sum of government consumption expenditure by federal and local government and gross capital formation by the government. Regarding the wage data, there are no series available for the longer period. So, being consistent with Phan (2014), the real unit labour cost index is used as a proxy for a wage. Real unit labour cost is estimated by $\mathrm{ABS}$ as the ratio of average labour cost to average labour productivity and deflated by GDP deflator. Employment is estimated as the percentage of total employed person to 
the stock of total labour force. For hours worked, total hours worked in all jobs is used. In this study, overnight cash rate is used as the monetary policy variable because the Reserve Bank of Australia (RBA) adjust monetary policy by changing this rate. The monthly series of overnight cash rate is converted into quarterly series by taking average throughout the corresponding quarter. This data series is taken from the RBA. The study starts with $19853^{\text {rd }}$ quarter and ends at $20151^{\text {st }}$ quarter. The study period is taken based on the availability of quarterly series of total hours worked.

The data set for US real GDP is collected from Federal Reserve Bank of St. Luis. Finally, the series of thr dummy variable is created to capture the effect of GFC and it is treated as an exogenous because GFC was observed outside the Australia. Based on Romer (2012) GFC is dated from $20073^{\text {rd }}$ quarter to $20091^{\text {st }}$ quarter. All of the variables except interest rate and employment rate are appear in the logarithmic form. The details of the data used in the model are presented in appendix (Table 1)

\subsection{Lag length criteria, Co-integration test and VAR stability test}

Suggestion based on AIC criterion, 2 lags are chosen. This is justifiable considering the number of endogenous variables used in the model and sample period taken for the study.

Johansen co-integration test for both trace-test and maximum eigenvalue test report the probability value less than 0.05 , so we reject null hypothesis of 'no co-integration'. The unit circle presented in the appendix (table 2) suggests that no root lies outside the unit circle. Hence, VAR stability condition is satisfied.

\section{Result and discussion}

The major labour market variables used to account the macroeconomic policy shocks are output, unit labour cost, employment and total hours worked. Impulse responses are used to analyses the effects of these shocks on the labour market. The responses are measured in Cholesky one standard deviation innovation for each shock. The dash lines represent the confidence interval.

\subsection{Effects of cash rate shock}

The impulse response functions after contractionary monetary policy shock are presented in figure 1. If central bank increases cash rate by 42 basis points, unit labour 
cost increases significantly and reaches its peak at quarter six and come back to its original level after four and half years. The response is significant between quarter three and quarter eight. Total hours worked and employment reacts in the same direction. Both responses are marginally positive within third quarter and negative afterward. The response of hours worked reaches it minimum at quarter ten with 0.3 percentage points below the original level and is significant. It comes back to its original level after five years. Similarly, the response of employment reaches its minimum at quarter eleven and is marginally significant on its minimum. It comes back to its trend level after four and half years. Output, household consumption and private investment decrease as expected. However, only the response of private investment is significant. Tax responses negatively as expected and it is significant at its minimum. Government spending also reacts negatively over time with initial positive response in the first twoquarters.

Figure-1 (effects of cash rate shock)
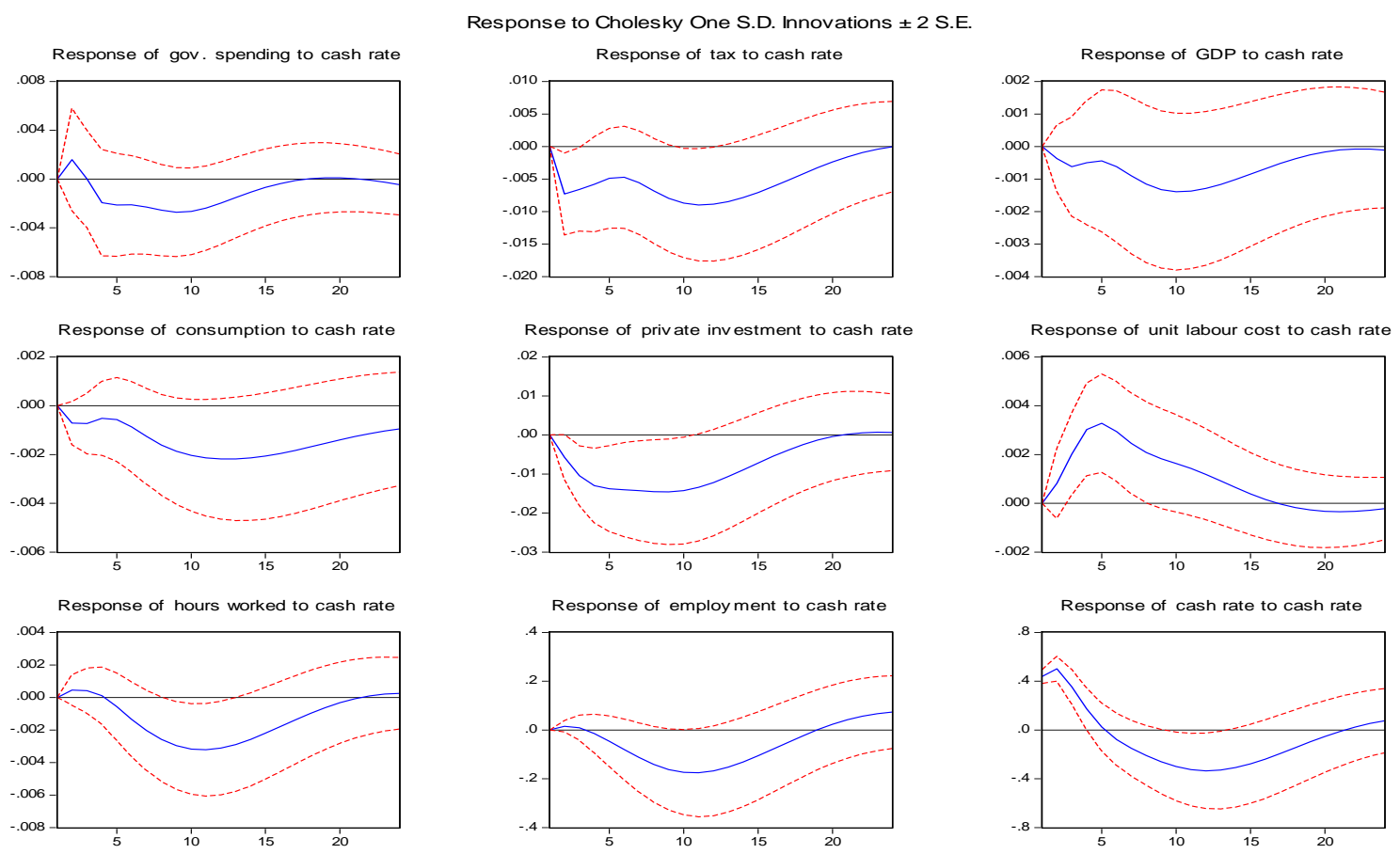

The results suggest that following the contractionary monetary policy shock both investment and consumption falls and consequently lowers the output demand. Firms respond by adjusting their inputs which cause the decline in output and employment. Following this scenario, the real wage is expected to decrease. However, due to the positive response of unit labour cost, results are difficult to interpret according to the recent theoretical assumption of New Keynesian DSGE model. Overall results are 
similar to Peersman \& Smets (2001) for Euro area. The responses of hours and employment are similar to the Tagkalakis (2006) for the UK and Christiano et al. (1999) for the US.

\subsection{Effects of government spending shock}

The responses of positive government spending shocks are presented in figure 2 . In response of positive government spending shock unit labour cost shows a positive response within three-quarters and it starts to decline. It reaches its minimum after six quarters and come back to original level after three years. However, the response is not significant. Total hours worked and employment response positively and in line with the positive response of real output. Total hours worked reaches its maximum level after seven quarters with 0.14 percentage point higher compared to initial level. It comes back to original level after four years. Employment increases which is significant in first three quarters and reaches its maximum point after two years with one percentage point higher compared to its initial value and come back to original level after seventeen quarters. As a result of positive spending shock, real output, consumption and private investment increase as expected. Interest rate responses positively after one year.

Figure 2 (effects of government spending shock)

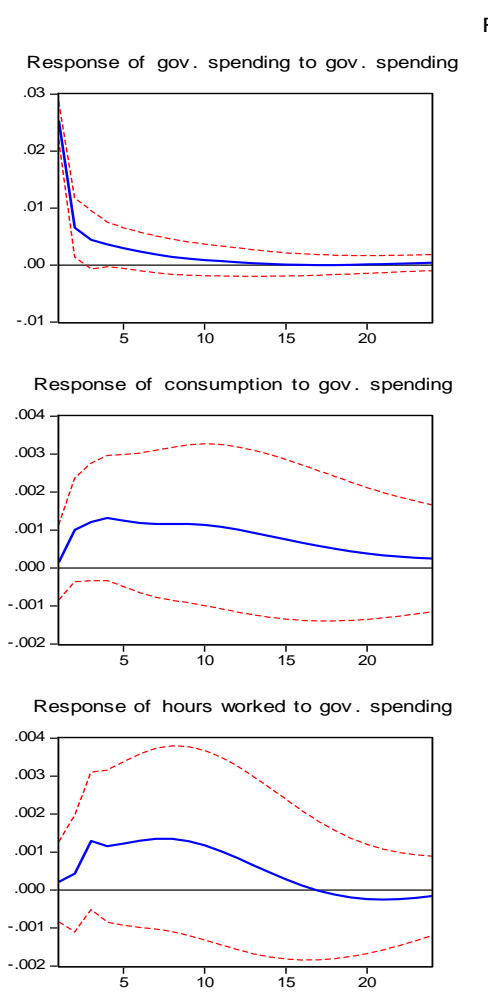

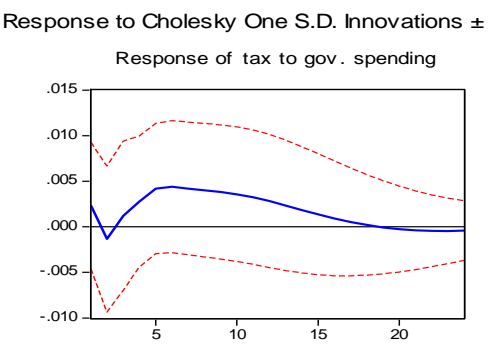

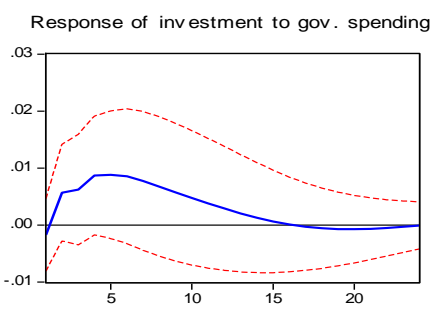

Response of employment to gov. spending

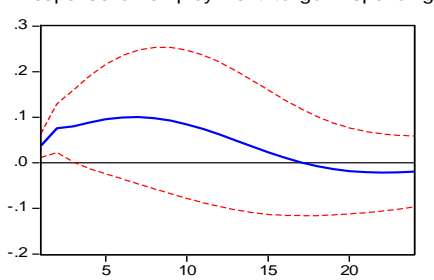

Response of GDP to gov. spending

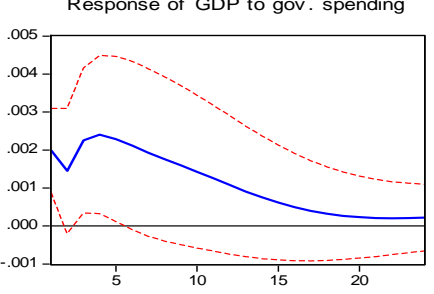

Response of unit labour cost to gov. spending

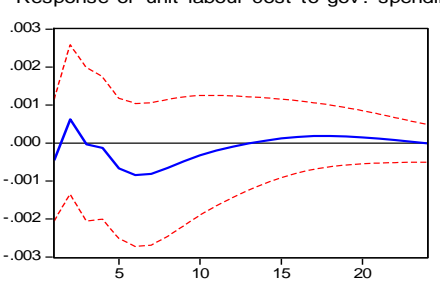

Response of cash rate to gov. spending

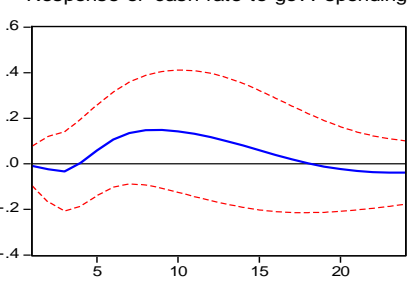


The results suggest that responding the positive government spending, households increase their labour supply due to the negative wealth effect. As a result employment and total hours worked increases. The short term positive response of unit labour cost indicates the positive response of real wage. The response of government spending to its own shock is not persistent as it is significant only in first three-quarters. The majority of the labour market responses after positive government spending shocks are in line with Bruckner \& Pappa (2012) for OECD countries and Kato \& Miyamato (2013) for Japan.

\subsection{Variance decomposition}

Variance decomposition helps to analyze the effect of each of the shock on the set of endogenous variable included in the model. The variance decompositions are done on the same assumption of Cholesky ordering as done for the impulse responses. The variance decomposition for each variable is presented in the table 1 . The variation due to monetary policy shock on the labour market is significantly higher comparing to a fiscal shock. For instance, the variation on unit labour cost caused by government spending shock is 0.40 and 1.24 percentage on $4^{\text {th }}$ and $24^{\text {th }}$ quarter respectively. On the other hand, at the same quarter variation due to interest rate 
Table-1 (Variance decomposition)

Dvariance decomposition (quarter: 1, 4, 12, 24)

\begin{tabular}{|c|c|c|c|c|c|c|c|c|c|c|c|}
\hline Variabe & Shock & 1 & 4 & 12 & 24 & Variable & Shock & 1 & 4 & 12 & 24 \\
\hline \multirow[t]{9}{*}{$\mathrm{G}$} & g & 100.00 & 76.90 & 58.73 & 53.52 & \multirow[t]{9}{*}{$c$} & $\mathrm{~g}$ & 0.08 & 4.31 & 4.73 & 3.84 \\
\hline & $\mathrm{t}$ & 0.00 & 1.16 & 1.10 & 1.57 & & $\mathrm{t}$ & 1.59 & 6.94 & 6.43 & 4.71 \\
\hline & $y$ & 0.00 & 5.09 & 8.69 & 8.03 & & $y$ & 2.61 & 8.97 & 12.45 & 9.51 \\
\hline & c & 0.00 & 9.36 & 13.67 & 17.61 & & c & 95.72 & 75.24 & 52.06 & 47.27 \\
\hline & inv & 0.00 & 0.24 & 0.31 & 0.61 & & inv & 0.00 & 0.50 & 2.78 & 2.22 \\
\hline & w & 0.00 & 0.43 & 6.36 & 6.01 & & w & 0.00 & 1.92 & 8.25 & 10.10 \\
\hline & $\mathrm{h}$ & 0.00 & 2.93 & 3.65 & 3.64 & & $\mathrm{~h}$ & 0.00 & 0.59 & 4.79 & 10.01 \\
\hline & I & 0.00 & 3.18 & 3.38 & 496.00 & & I & 0.00 & 0.19 & 0.94 & 0.66 \\
\hline & $\mathrm{i}$ & 0.00 & 0.67 & 4.07 & 4.03 & & $\mathrm{i}$ & 0.00 & 1.34 & 7.57 & 11.68 \\
\hline \multirow[t]{9}{*}{$\mathrm{T}$} & g & 0.38 & 0.64 & 2.64 & 2.38 & \multirow[t]{9}{*}{ inv } & $g$ & 0.25 & 3.75 & 4.71 & 4.21 \\
\hline & $\mathrm{t}$ & 99.62 & 75.77 & 43.12 & 35.66 & & $t$ & 11.58 & 19.09 & 10.54 & 9.42 \\
\hline & $y$ & 0.00 & 6.05 & 11.82 & 10.34 & & $y$ & 25.94 & 27.22 & 21.61 & 19.43 \\
\hline & c & 0.00 & 1.14 & 5.72 & 6.88 & & c & 0.28 & 3.04 & 7.19 & 8.97 \\
\hline & inv & 0.00 & 6.00 & 10.85 & 9.17 & & inv & 61.95 & 34.33 & 17.72 & 15.76 \\
\hline & w & 0.00 & 1.68 & 4.14 & 5.90 & & w & 0.00 & 0.48 & 7.74 & 8.07 \\
\hline & $\mathrm{h}$ & 0.00 & 0.51 & 5.09 & 11.08 & & $\mathrm{~h}$ & 0.00 & 0.16 & 8.15 & 11.64 \\
\hline & I & 0.00 & 3.00 & 5.54 & 4.78 & & I & 0.00 & 4.14 & 4.23 & 4.04 \\
\hline & i & 0.00 & 5.18 & 11.04 & 13.77 & & i & 0.00 & 7.79 & 18.12 & 18.47 \\
\hline \multirow[t]{9}{*}{$\mathrm{Y}$} & g & 10.40 & 11.06 & 12.39 & 11.33 & \multirow[t]{9}{*}{ w } & g & 0.28 & 0.40 & 1.24 & 1.24 \\
\hline & $\mathrm{t}$ & 15.26 & 14.92 & 9.87 & 8.89 & & $t$ & 2.97 & 6.53 & 5.20 & 5.22 \\
\hline & $y$ & 74.33 & 71.05 & 62.74 & 55.58 & & $y$ & 6.61 & 7.07 & 9.09 & 9.25 \\
\hline & c & 0.00 & 1.77 & 5.16 & 10.02 & & $c$ & 0.80 & 3.05 & 3.48 & 3.86 \\
\hline & inv & 0.00 & 0.16 & 0.45 & 0.55 & & inv & 2.57 & 4.38 & 3.17 & 3.45 \\
\hline & $w$ & 0.00 & 0.30 & 3.66 & 3.98 & & w & 86.79 & 63.05 & 45.86 & 43.88 \\
\hline & $\mathrm{h}$ & 0.00 & 0.13 & 2.04 & 2.80 & & $\mathrm{~h}$ & 0.00 & 0.58 & 6.30 & 7.41 \\
\hline & I & 0.00 & 0.09 & 0.43 & 2.95 & & 1 & 0.00 & 5.90 & 5.42 & 5.75 \\
\hline & $\mathrm{i}$ & 0.00 & 0.50 & 3.27 & 3.89 & & $\mathrm{i}$ & 0.00 & 9.03 & 20.25 & 19.94 \\
\hline \multirow[t]{9}{*}{$\mathrm{H}$} & $g$ & 0.14 & 2.33 & 3.45 & 2.99 & \multirow[t]{9}{*}{$\bar{i}$} & $g$ & 0.04 & 0.15 & 2.75 & 2.38 \\
\hline & $\mathrm{t}$ & 2.65 & 20.18 & 12.89 & 10.60 & & $\mathrm{t}$ & 3.72 & 6.78 & 5.21 & 5.45 \\
\hline & $y$ & 0.08 & 5.17 & 14.04 & 12.49 & & $y$ & 0.37 & 0.75 & 11.88 & 10.22 \\
\hline & $c$ & 0.15 & 4.53 & 9.48 & 11.17 & & $c$ & 0.02 & 13.75 & 9.45 & 7.24 \\
\hline & inv & 3.01 & 5.87 & 8.16 & 6.91 & & inv & 0.05 & 8.20 & 9.97 & 8.43 \\
\hline & w & 0.37 & 1.26 & 10.94 & 11.57 & & w & 2.82 & 2.56 & 9.18 & 10.98 \\
\hline & $\mathrm{h}$ & 93.60 & 50.43 & 20.36 & 21.31 & & $\mathrm{~h}$ & 0.02 & 2.69 & 6.94 & 15.94 \\
\hline & I & 0.00 & 9.96 & 8.59 & 8.10 & & I & 5.52 & 15.56 & 22.52 & 17.24 \\
\hline & $\mathrm{i}$ & 0.00 & 0.27 & 12.11 & 14.85 & & $\mathrm{i}$ & 87.45 & 49.55 & 22.10 & 22.11 \\
\hline \multirow[t]{9}{*}{$\mathrm{L}$} & $g$ & 6.89 & 6.75 & 5.45 & 4.55 & & & & & & \\
\hline & $\mathrm{t}$ & 9.31 & 12.78 & 4.59 & 5.99 & & & & & & \\
\hline & $y$ & 1.35 & 16.59 & 22.50 & 18.77 & & & & & & \\
\hline & $c$ & 3.84 & 7.40 & 4.15 & 4.14 & & & & & & \\
\hline & inv & 1.50 & 3.73 & 3.85 & 5.37 & & & & & & \\
\hline & $w$ & 3.39 & 2.51 & 12.28 & 12.29 & & & & & & \\
\hline & $\mathrm{h}$ & 2.92 & 0.75 & 10.24 & 16.00 & & & & & & \\
\hline & I & 70.81 & 49.33 & 26.89 & 21.31 & & & & & & \\
\hline & i & 0.00 & 0.16 & 10.06 & 11.57 & & & & & & \\
\hline
\end{tabular}


shock are 9.03 and 19.94 percentage respectively. Similarly, the impacts of fiscal shock on total hours worked and employment are 2.99 and 4.55 percentage respectively for $24^{\text {th }}$ quarter whereas impacts of monetary policy shock are 14.85 and 11.57 percentage respectively. The major share of variation on output is caused by fiscal variables. For instance, the variation caused by government spending shock is $10.40,11.06$ and 11.33 percentage in $1^{\text {st }}, 4^{\text {th }}$ and $24^{\text {th }}$ quarter respectively. But variation due to cash rate shock is accounted as 0.50 and 3.89 percentage for $4^{\text {th }}$ and $24^{\text {th }}$ quarter respectively.

\section{Conclusion}

This paper analyses the dynamic response of labour market variables; output, total hours worked, unit labour cost and employment to cash rate and government spending shock in Australia using a VAR method. The recursive identification approach is used to analyze the effects of monetary policy and fiscal policy shocks on the Australian labour market. The result suggests that after positive shock on cash rate both total hours worked and employment falls, however, unit labour cost increases. At the same time, the results suggest that household consumption, private investment and real output decreases. The responses of hours and employment are similar to Tagkalakis (2006) for the UK, Christiano et al. (1999) for US and Peersman and Smets (2001) for Euro area. After positive shock on government spending, both hours worked and employment increases. However, unit laboour cost responses positively for first threequarters than it shows a negative response. Household consumption, private investment and real output increases following positive government spending shock as expected. Dynamic responses of labour market after positive government spending shocks are consistent with Bruckner and Pappa (2012) for OECD countries and Kato and Miyamato (2013) for Japan. Variance decomposition shows that labour market dynamics is less explained by fiscal policy shocks comparing to monetary policy shock. 


\section{Appendix}

\section{Table 1 (data description and sources)}

\begin{tabular}{|c|c|c|}
\hline Variable & Code & Description and sources \\
\hline $\begin{array}{l}\text { Government } \\
\text { spending }\end{array}$ & g & $\begin{array}{l}\text { Chain Volume measure of seasonally adjusted government } \\
\text { consumption expenditure plus government gross capital } \\
\text { formation, ABS }\end{array}$ \\
\hline Net taxes & $\mathrm{t}$ & Seasonally adjusted total taxes minus transfer of payment, ABS \\
\hline Real GDP & $y$ & $\begin{array}{l}\text { Chain Volume measure of seasonally adjusted gross domestic } \\
\text { product, ABS }\end{array}$ \\
\hline Consumption & c & $\begin{array}{l}\text { Chain Volume measure of seasonally adjusted finale households } \\
\text { consumption expenditure, ABS }\end{array}$ \\
\hline Unit labour cost & w & Seasonally adjusted real unit labour cost index, ABS \\
\hline Total hours worked & $\mathrm{h}$ & Seasonally adjusted quarterly hours worked in all jobs, ABS \\
\hline Employment & 1 & $\begin{array}{l}\text { Seasonally adjusted, percentage pf total employed person out } \\
\text { of labour force, ABS, monthly data series are converted into } \\
\text { quarterly by taking average. }\end{array}$ \\
\hline Cash rate & $\mathrm{i}$ & Quarterly average of the target overnight cash rate, RBA \\
\hline $\begin{array}{l}\text { United States Real } \\
\text { GDP }\end{array}$ & $\mathrm{y}^{*}$ & $\begin{array}{l}\text { Seasonally Adjusted real gross domestic product, FRED, } \\
\text { series ID:GDPMC1 }\end{array}$ \\
\hline
\end{tabular}

\section{Table-2 (VAR Stability test)}

\begin{tabular}{cc} 
Root & Modulus \\
\hline \hline $0.961149-0.037907 i$ & 0.961896 \\
$0.961149+0.037907 i$ & 0.961896 \\
$0.905095-0.213812 i$ & 0.930007 \\
$0.905095+0.213812 i$ & 0.930007 \\
0.915340 & 0.915340 \\
$0.701504-0.043554 i$ & 0.702855 \\
$0.701504+0.043554 i$ & 0.702855 \\
$0.503260-0.274300 i$ & 0.573159 \\
$0.503260+0.274300 i$ & 0.573159 \\
$0.385436+0.423573 i$ & 0.572691 \\
$0.385436-0.423573 i$ & 0.572691 \\
-0.419927 & 0.419927 \\
$-0.113087-0.324293 i$ & 0.343445 \\
$-0.113087+0.324293 i$ & 0.343445 \\
$-0.304232-0.127240 i$ & 0.329768 \\
$-0.304232+0.127240 i$ & 0.329768 \\
$0.036280-0.024657 i$ & 0.043866 \\
$0.036280+0.024657 i$ & 0.043866 \\
\hline \hline
\end{tabular}

Inverse Roots of AR Characteristic Polynomial

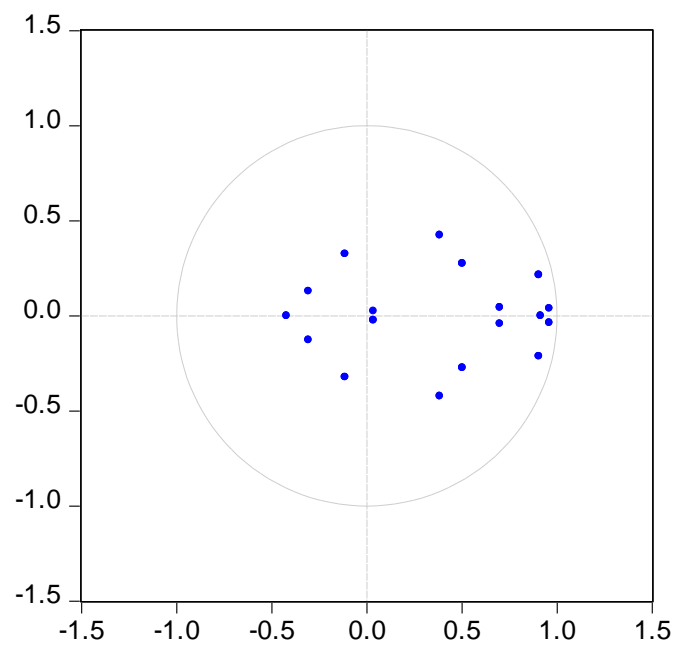

No root lies outside the unit circle.

VAR satisfies the stability condition. 


\section{Reference}

Australian Bureau of Statistics (ABS) 2010, The labour market during recent economic downturn, viewed 25 October 2015,

<http://www.ausstats.abs.gov.au/ausstats/subscriber.nsf/LookupAttach/4102.0Publication16.03.1 03/\$File/41020_Labourmarket.pdf>.

Bilbiie, FO, Meier, A \& Müller, GJ 2008, 'What accounts for the changes in US fiscal policy transmission?', Journal of Money, Credit and Banking, vol. 40, no. 7, pp. 1439-1470. http://dx.doi.org/10.1111/j.1538-4616.2008.00166.x.

Blanchard, O \& Perotti, R 2002, 'An empirical characterization of the dynamic effects of changes in government spending and taxes on output', Quarterly Journal of Economics, vol. 117, no. 4, pp. 1329-1368. http://dx.doi.org/10.1162/003355302320935043.

Brückner, M \& Pappa, E 2012, 'Fiscal expansions, unemployment, and labor force participation: theory and evidence', International Economic Review, vol. 53, no. 4, pp. 1205-1228. http://dx.doi.org/10.1111/j.1468-2354.2012.00717.x.

Caldara, D \& Kamps, C 2008, 'What are the effects of fiscal policy shocks? A VAR-based comparative analysis', viewed 27 October 2015,

<http://papers.ssrn.com/sol3/papers.cfm?abstract_id=1102338>.

Christiano, LJ, Eichenbaum, M \& Evans, CL 1999, Monetary policy shocks: what have we learned and to what end?, National Bureau of Economic Research, viewed 27 October 2015, $<$ <ttp://www.nber.org/papers/w6400>.

Daly et al. 2014, 'Labour markets in the global financial crisis: the good, the bad and the ugly', working paper, no. 2014-11, Federal Reserve Bank of San Francisco, viewed 25 October 2015, < http://www.frbsf.org/economic-research/publications/working-papers/wp2014-11.pdf>.

Dungey, M \& Fry, R 2010, 'Fiscal and Monetary Policy in Australia: An SVAR Model', working paper, viewed 27 October 2015, <http://home.bi.no/a0310125/workshop/Dungey.pdf>.

Dungey, M \& Pagan, A 2000, 'A Structural VAR model of the Australian economy', Economic Record, vol. 76, no. 235, pp. 321-342. http://dx.doi.org/10.1111/j.1475-4932.2000.tb00030.x.

Dungey, M \& Pagan, A. 2009, 'Extending a SVAR model of the Australian economy', Economic Record, vol. 85, no. 268, pp. 1-20. http://dx.doi.org/10.1111/j.1475-4932.2008.00525.x.

International Monetary Fund 2009, 'Fiscal implication of the global economic and financial crisis', International Monetary Fund, Staff Position Note, SPN/09/13, viewed 27 October 2015, < https://www.imf.org/external/pubs/ft/spn/2009/spn0913.pdf>.

Kato, RR \& Miyamoto, H 2013, 'Fiscal stimulus and labor market dynamics in Japan', Journal of the Japanese and International Economies, vol. 30, pp. 33-58. http://dx.doi.org/10.1016/j.jjie.2013.10.001.

Monacelli, T, Perotti, R \& Trigari, A 2010, 'Unemployment fiscal multipliers', Journal of Monetary Economics, vol. 57, no. 5, pp. 531-553. http://dx.doi.org/10.1016/j.jmoneco.2010.05.009

Peersman, G \& Smets F 2001, 'The monetary transmission mechanism in the euro area: more evidence 
from VAR analysis', European Central Bank working paper no. 91, viewed 30 October 2015, < http://zentral-bank.eu/pub/pdf/scpwps/ecbwp091.pdf>.

Perotti, R., 2005, 'Estimating the effects of fiscal policy in OECD countries', Proceedings, Federal Reserve Bank of San Francisco, viewed 29 October 2015, < http://www.frbsf.org/economics/conferences/0503/fpoecd.pdf>.

Phan, T 2014, 'Output composition of the monetary policy transmission mechanism: is Australia different?', Economic Record, vol. 90, no. 290, pp. 382-399. http://dx.doi.org/10.1111/14754932.12121 .

Romer, D 2012, Advanced macroeconomics $4^{\text {th }}$ edition, McGraw Hill, Irwin, the United States.

Sims, C 1980, 'Macroeconomics and reality', The Econometrica, vol. 48, no. 1, pp. 1-48. http://dx.doi.org/10.2307/1912017.

Tagkalakis, A 2006, 'The effects of macroeconomic policy shocks on the UK labour market', International Journal of Finance \& Economics, vol. 11, no. 3, pp. 229-244. http://dx.doi.org/10.1002/ijfe.295.

Yuan, M \& Li W 2000, 'dynamic employment and hours effects of government spending shocks', Journal of Economic Dynamics and Control, vol. 24, no. 8, pp. 1233-1263. http://dx.doi.org/10.1016/S01651889(99)00007-X. 